\title{
PRELIMINARY STUDY FOR THE EFFECT OF TRAMADOL ADDICTION ON FUNCTIONAL AND STRUCTURAL INTEGRITY OF RENAL PROXIMAL TUBULES AMONG ADDICTED EGYPTIANS
}

\author{
El-Safty IAM ${ }^{1}$, Elgamel $\mathrm{O}^{2}$, Shoman $\mathrm{AE}^{3}$, El-Deen IEM ${ }^{4}$, El-Rasheed $\mathrm{AH}^{2}$, Sadek $^{2}$ \\ and El-Ashmawy MFM'.
}

Departments of ${ }^{1}$ Biochem. Sec., Chem., Faculty of Education, ${ }^{2}$ Institute of Psychiatry, ${ }^{3}$ Community, Environmental and Occupation Med., Fac. of Med., Ain Shams University, ${ }^{4}$ Chemistry, Faculty of Science, Port-Saed University.

\begin{abstract}
:
Experimental animals and human post-mortem studies concerning renal effects of tramadol addiction showed histopathological changes in proximal tubules. This study investigates early changes in function and structure of proximal tubules to tramadol addiction. The study included 44 males $\left(G_{1}=23\right.$ controls, $G_{2}=21$ tramadol addicts). The measured urinary parameters were: urinary alpha-1-microglobulin $\left(U . \alpha_{1}-m\right)$, urinary leucine aminopeptidase (U.LAP), urinary N-acetyl- $\beta$-D-glucosaminidase (U.NAG). Urinary tramadol (U.Tr) was measured in $G_{2}$. In $G_{2}$, levels of U. $\alpha_{1}-m$, U.LAP and U.NAG were increased in comparison with $G_{1}$. These changes were insignificant. U.Tr did not show any correlation with any parameter in $G_{2}$. Tramadol addiction may affect proximal tubules. This study is a Preliminary assessment for the subclinical renal effects of tramadol.
\end{abstract}

Keywords: Alpha-1-microglobulin, Tramadol, Leucine aminopeptidase, N-acetyl-beta-D-glucosaminidase, Nephrotoxicity.

\section{INTRODUCTION:}

In Egypt, drug addiction is considered one of the serious problems that worry both people and the government. It affects young people within their productive years. It may lead to many problems such as social maladaptation, decreased work productivity and job loss (El-Akabawi, 2001).

Tramadol hydrochloride was initially developed in the 1970's. It was registered in 1977 in Germany, 1994 in the UK, and 1995 in the US (Grond, et al, 2004). Clinical and experimental studies demonstrated that tramadol did not induce tolerance and dependence on repeated administration (Miranda, et al, 1998 and Kitahara, et al, 2009). On the other hand, results of other studies suggest that tramadol may have abuse liability under some conditions or in certain populations (Jjaderborn, et al, 2009 and Lanier, et al, 2010). Post-marketing surveillance studies consistently showed that the abuse and diversion of tramadol was relatively low (Knisely, et al, 2002). However, a significant finding was that for the cases of tramadol abuse, $97 \%$ of the drug addicts used tramadol in combination with other drugs or they had a previous history of addiction to substance of abuse (Cicero, et al, 1999), implying that the abuse liability of trama- dol might be ignored in poly-drug abuser population (Degenhardt, et al, 2006). Another epidemiological surveys demonstrated that tramadol was very popular in the drug abuse population, which was often used as a substitutive for heroin and other opioids, or combined with other drugs to achieve certain desired effects, or to avoid some undesired effects (Li, et al, 2011 and Liu, et al, 2011), indicating that tramadol may have a higher abuse liability when co-abused with other opioids even though the abuse potential of tramadol itself is relatively low.

In humans body, tramadol undergoes extensive and complex metabolism in the liver via cytochrome P450 system, with 23 metabolites identified: 11 phase I identified and 12 phase II conjugates (Wu, et al, 2002). Thirty per cent of the tramadol is excreted through the kidneys unmetabolised, while the remaining is metabolised by $\mathrm{O}$-and $\mathrm{N}$-demethylation, followed by conjugation with glucuronic acid and sulphates (Gutustein, et al, 2001 and Leppert, et al, 2011).

Metabolites of the drugs that are excreted from kidneys may cause cellular damage leading to kidney dysfunction. Various urinary parameters of the kidney such as alpha-1-microglobu$\operatorname{lin}\left(\alpha_{1}-\mathrm{m}\right)$ was proved useful to assess functional integrity of proximal tubules whereas urinary 
kidney-specific enzymes such as brush-border leucine-aminopeptidase (LAP) and lysosomal $\mathrm{N}$-acetyl- $\beta$-D-glucosaminidase (NAG) are indicators for structural integrity of proximal tubules (Mueller, et al, 1997).

The present work is a preliminary study to investigate the effect of tramadol addiction among Egyptian drug addicts on proximal tubular functional and structural integrity by measuring urinary kidney parameters as indicators of early alterations of the kidney normal function.

\section{SUBJECTS AND METHODS:}

\section{A) Subjects:}

Male drug addicted participated in the present study were recruited on voluntary bases from those attended the out-patient clinic, Institute of Psychiatry, Ain-Shams University, for treatment of drug addiction. All participants were subjected to interview using a questionnaire designed to obtain information on previous medical and occupational history, medication intake, actual health status, and subjective symptoms. All subjects underwent a routine clinical examination and a routine urinalysis. The interview and clinical examination were performed by the clinic physicians under the supervision of one of the authors. The drug addicts were excluded from the present study if they had:

1. A history of kidney disease or any disease likely to impair renal function or affect the urinary excretion of the investigated parameters (e. g. diabetes mellitus, hypertension, urinary tract disease).

2. A previous or present exposure to agents capable of damaging the kidney (heavy metals such as lead, cadmium and other nephrotoxins such as organic solvents).

3. Regular and prolonged treatment by drugs affecting the kidney (e. g. aminoglycosides).

4. Dental mercury amalgam fillings as it may affect the kidney.

Forty four Males were then included in the study. The tramadol addicts group $\left(\mathrm{G}_{2}\right)$ was comprised of 21 males (age: $18-40$ years, mean \pm SD: $28.71 \pm 6.64$, addiction duration: 6 months
- 17 years, mean $\pm \mathrm{SD}: 4.41 \pm 4.12)$, Another 23 healthy non-addicted males $\left(\mathrm{G}_{1}\right)$ (age: 19-38 years, mean \pm SD: $25.44 \pm 5.25)$ were recruited from relatives of the addicted participants after applying the same exclusion criteria and clinical examination.

\section{B) Biological Sampling and Methods:}

Morning urine sample was suggested as the best sample for detecting early kidney abnormalities (Zuppi, et al, 1995). Spot morning urine sample was collected by each participant who was instructed to void the urine sample directly into $100 \mathrm{ml}$ sterilized plastic container and centrifuged at $4500 \mathrm{rpm}$ for 5 minutes, and then the clear supernatant was distributed in polyethylene vials ( $1.5 \mathrm{ml}$ capacity). One vial was used on the same day the urine was collected for measuring tramadol using Immunalysis Tramadol EIA kit (Immunalysis Corporation, USA), and the instrument Biolis 24i Premium (Tokyo Boeki Medical System, Japan). According to the manufacturer of the kit, the method has $100 \%$ correlation with $\mathrm{GC} / \mathrm{MS}$ when $200 \mathrm{ng} / \mathrm{ml}$ cutoff calibrator is used. The rest of the vials were stored at $-20^{\circ} \mathrm{C}$ without preservatives until analyzed within 2 weeks for the assessment of:

1. Tubular function by measuring urinary alpha-1-microglobulin (U. $\left.\alpha_{1}-\mathrm{m}\right)$ using ELISA method kit (Assaypro, USA).

2. Tubular structural integrity by measuring urinary activities of Leucine-aminopeptidase (U.LAP) using kit from Randox (UK) and Nacetyl- $\beta$-D-glucosaminidase (U.NAG) using kit from Diazyme (USA).

3. Urinary creatinine concentration (U.Cr) using kit from Greiner Diagnostic GmbH (Germany).

Spot urine measurements were used because it has been shown that urinary protein/creatinine ratio (Lemann, et al, 1987) and enzyme activity/ creatinine (Jung, 1991) in a random urine sample correlate with 24-hour urinary excretion and eliminate variations caused by changing rates of urine output and provide a measure independent of urine concentration.

C) Statistical Analysis: 
Data were presented as mean \pm SD. Student t-test was used to compare between the means of parametric data, while Mann-Whitney test was used for non-parametric data. Correlation coefficient ( $r$ ) was calculated to test the association between two quantitative variables. P-values $<$ 0.05 were considered statistically significant. SPSS version 16.0 was used.

\section{RESULTS AND DISCUSSION:}

Among $\mathrm{G}_{1}$, data of the present study (Table 1) showed a positive correlation between age and each of U.LAP $(r=0.492 . P=0.017)$ and $U . \alpha_{1}-$ $\mathrm{m}(\mathrm{r}=0.521, \mathrm{P}=0.011)$. Also, regarding the age, the present results (Table 2 ) showed insignificant difference $(P>0.05)$ between $G_{1}$ and $G_{2}$. Urinary parameters of function and structure of proximal tubules was increased (Table 2). These changes were statistically insignificant $(\mathrm{P}>0.05)$. Furthermore, U.Tr/U.Cr showed no correlation with any of the measured urinary parameters in $\mathrm{G}_{2}$ (Table 3).
Results of the present study (Tables 1 and 2) demonstrated that structural and functional integrity of proximal tubules are deteriorated with age, supporting the report that structural and physiological changes in the kidney are associated with aging (Musso, et al, 2011), and that $\mathrm{G}_{1}$ matched with $\mathrm{G}_{2}$ to avoid the effect of age on the measured urinary parameters. Substances with the potential to be abused may have direct or indirect effects on physiologic mechanisms that lead to organ system dysfunction and disease. A multitude of renal diseases are associated with drug abuse because of many different substances used with widely varying pharmacologic effects. Such drugs have been associated with several renal syndromes by varied mechanisms (Kimmel, et al, 2001).

Although total protein in urine provides information of severity of proteinuria, it is protein type that renders a more specific picture of protein composition of urine. Data of the present study

Table (1): Correlation Coefficient ( $r$ ) between age and urinary parameters of $G_{1}$ :-

\begin{tabular}{|c|c|c|c|}
\hline & U.NAG/U Cr & U.LAP/U Cr & U. $\alpha 1-\mathrm{m} / \mathrm{U} . \mathrm{Cr}$ \\
\hline Age & 0.057 & $0.492^{*}$ & $0.521^{*}$ \\
\hline
\end{tabular}

* $r$ is statistically significant as $(P<0.05)$.

Table (2): Comparison (Mean \pm SD) between variables of the different studied groups:-

\begin{tabular}{|l|c|c|c|}
\hline \multicolumn{1}{|c|}{ Parameter } & $\mathrm{G} 1$ & $\mathrm{G} 2$ & $\mathrm{P}$ \\
\cline { 2 - 4 } & $\mathrm{N}=23)$ & $(\mathrm{N}=21)$ & \\
\hline A) Age (years) & $25.44 \pm 5.25$ & $28.71 \pm 6.64$ & $>0.05$ \\
$\begin{array}{c}\text { B) Tubular Functional integrity } \\
\text { U.a1-m/U.Cr }(\mu \mathrm{g} / \mathrm{mg} \mathrm{cr})\end{array}$ & $7.70 \pm 5.18$ & $10.42 \pm 11.89$ & $>0.05$ \\
C) Tubular Structural integrity & & & \\
$\quad$ U.NAG/U.Cr (U/mg cr) & $9.15 \pm 6.21$ & $11.35 \pm 9.57$ & $>0.05$ \\
U.LAP/U.Cr (U/mg cr) & $5.52 \pm 3.68$ & $7.45 \pm 14.03$ & $>0.05$ \\
\hline
\end{tabular}

N (Number of volunteer).

Table (3): Correlation coefficient (r) between different urinary parameters and level of Urinary tramadol in addicted group:-

\begin{tabular}{|c|c|}
\hline \multirow{2}{*}{ Uninary parameter } & G2 \\
\cline { 2 - 2 } & U.Tr/U.Cr \\
\hline U.NAG/U.Cr & 0.104 \\
U.LAP/U.Cr & 0.095 \\
U.a1-m/U.Cr & -0.252 \\
\hline
\end{tabular}

$r$ is statistically insignificant as $(P<0.05)$,

U. Tr/U. Cr (Urinary Tramadol urinary creatinine ratio),

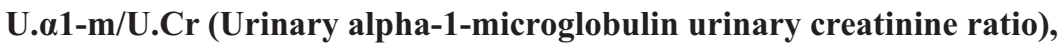

U.LAP/U.Cr (Urinary Leucine-aminopeptidase urinary creatinine ratio),

U.NAG/U.Cr (Urinary N-acetyl- $\beta$-D-glucosaminidase urinary creatinine ratio),

G2 (Tramadol addicts group). 
(Table 2) for the effect of tramadol addiction on proximal tubular function showed an increase in the urinary excretion of $\alpha_{1}-\mathrm{m}$ in $G_{2}$, suggesting impairment in renal proximal tubular reabsorption function, but the increased level was insignificant when compared with $G_{1}$. This suggestion is supported by other investigators who reported a histopathological changes in renal tubules due to tramadol alone in animal experiments (Atici, et al, 2005) and in human post-mortem microscopy examination of a young patient who died of fatal tramadol intoxication due to acute tubular necrosis of the kidney (DeDecker et al, 2008).

Many enzymes have been detected in urine and a few appear to possess diagnostic relevance in recognition of renal injury. Choice of investigated urinary enzymes in this study was made on the basis of site specificity.

Data of the present study (Table 2) for the effect of tramadol addiction on the tubular structure showed an increase in the U.NAG and U.LAP excretion, but the increase was insignificant when compared with $\mathrm{G}_{1}$. The increased leakage of enzymes characteristic of these cells results from tubular damage, suggesting the possibility of a nephrotoxic effect of tramadol addiction. This suggestion is supported by other studies elsewhere that revealed proximal tubular histopathological effect due to tramadol alone in human post-mortem (DeDecker et al, 2008) and experimental studies in animals (Atici, et al, 2005).

Limitation of our study is that the number of participants classified as addicted was quite small. It was reported that both younger age and high doses were identified as risk factors for addiction (Edlund, et al, 2007 and Wasan, et al, 2007) and therefore the addicted out patients might have been reluctant to participate in the study realizing that they had addiction problems.

\section{Conclusions:}

Tramadol addiction may affect the function and structure of proximal tubules, although U.Tr level showed no correlation with any of the measured urinary parameters of proximal tubules. Albumin is the major plasma protein, and protein uptake is via a constitutive reabsorption pathway in the proximal tubule cells (Christensen, et al, 2007). The structural and functional changes to the proximal tubule cells are a key contributing factor to the development of excessive albumin loss in urine (albuminuria). Albumin present in the urine is often the first indicator of glomerular damage (Thrailkill, et al, 2009) and a decline in renal function. Therefore, the effect of longer addiction duration on the function and structure of both the glomeruli and proximal tubules needs further study.

\section{Acknowledgement:}

Authors would like to acknowledge the financial support provided by Ain-Shams University, Dr. Haytham Hassan and Dr. Rehab Naguib for drafting the questionnaire and physical examination as well as interviewing the participants.

\section{REFERENCES:}

Atici S, Cinel I, Cinel L, Doruk N, Eskandari G, Oral U. 2005. Liver and kidney toxicity in chronic use of opioids: An experimental long term treatment model. J Biosci; 30: 245-252.

Christensen E, Birn H, Rippe B, Maunsbach AB. 2007. Controversies in nephrology: renal albumin handling, facts, and artifacts! Kidney Int; 72: 11921194.

Cicero TJ, Adams EH, Geller A, Inciardi JA, Munoz A , Schnoll SH, et al. 1999. A post-marketing surveillance program to monitor Ultram (tramadol hydrochloride) abuse in the United States. Drug Alcohol Depend; 57: 7-22.

DeDecker K, Cordonnier J, Jacobs W, Coucke V , Schepens P, Jorens PG. 2008. Fatal intoxication due to tramadol alone: case report and review of the literature. Forensic Sci Int; 175: 79-82.

Degenhardt L, Black E, Breen C, Bruno R, Kinner S, Roxburgh A, et al. 2006. Trends in morphine prescriptions, illicit morphine use and associated harms among regular injecting drug users in Australia. Drug Alcohol Rev; 25:403-412.

Edlund MJ, Steffick D, Hudson T, Harris KM, Sullivan M. 2007. Risk factors for clinically recognized opioid abuse and dependence among veterans using opioids for chronic non-cancer pain. Pain;129: $355-$ 362.

El-Akabawi AS. 2001. Drug abuse in the arab world: a country profile of Egypt. In: Okasha A and Maj M, editors. Images in Psychiatry-An Arab Perspective. World Psychiatric Association Series. p. 143-150. 
Grond S, Sablotzki A. 2004. Clinical pharmacology of tramadol. Clin Pharmacokinet; 43: 879-923.

Gutustein HB and Akil H. 2001. Opioid analgesics. In: Hardman JG and Linobird LE, editors. Goodman and Gilman's The Pharmacological Basis of Therapeutics. New York: McGraw-Hill;. 10th ed. p. 569620.

Jjaderborn M, Jonsson AK, Ahlner J, Hagg S. 2009. Tramadol dependence: a survey of spontaneously repeated cases in Sweeden. Pharmacoepidemiol Drug Saf; 18: 1192-1198.

Jung K. 1991. Enzyme activities in urine. How should we express their excretion? Eur J Clin Chem Clin Biochem; 29: 725-729.

Kimmel PL, Alam S, Lew SQ. 2001. Renal disease in patients with substance abuse. In: Schena FP editor. Nephrology. London: McGraw-Hill;. p. 237-243.

Kitahara M, Kojima K, Hanada M, Kuriyama Y, Ohmura A. 2009. Effectiveness of oral tramadol hydrochloride for chronic non-malignant pain. Masui; 58: 971-975.

Knisely JS, Campbell ED, Dawson KS, Schnoll SH. 2002. Tramadol post-marketing surveillance in Health care professionals. Drug Alcohol Depend; 68: 15-22.

Lanier RK, Lofwall MR, Mintzer MZ, Bigelow GE, Strain EC. 2010. Physical dependence potential of daily tramadol dosing in humans. Psychopharmacology; 211: 457-466.

Lemann J Jr, Dowmans BT. 1987. Proteinuria in health and disease assessed by measuring the urinary protein/ creatinine ratio. Clin Chem; 33: 297-9.

Leppert W, Mikolajczak P. 2011. Analgesic effects and assays of controlled-release tramadol and O-desmethyltramadol in cancer patients with pain. Curr Pharmaceut Biotechnol; 12: 306-12.

Li C, Chen HF. 2011. 1158 cases report of heroin dependence. Med J Chinese People's Health; 23: 595-6.
Liu CJ, Qi L, Yang J. 2011. Survey of tramadol addiction in drug treatment agencies in Ningxia province. J Ningxia Medical University, 33: 67-9.

Miranda HF, Pinardi G. 1998. Antinociception, tolerance and physical dependence comparison between morphine and tramadol. Pharmacol Biochem Behav; 61: 357-360.

Mueller PW, Lash LH, Price RG, Stolte H, Gelpi E , Maack T. 1997. Urinary biomarkers to detect significant effects of environmental and occupational exposure to nephrotoxins. I. Categories of tests for detecting effects of nephrotoxins. Ren Fail; 19: 505521.

Musso CG, Oreopoulos DG. 2011. Aging and physiological changes of the kidneys including changes in glomerular filtration rate. Nephron Physiol; 119 (Suppl. 1): 1-5.

Thrailkill KM, Nimmo T, Bunn RC, Cockrell GE, Moreau CS, Mackintosh S, et al. 2009. Microalbuminuria in type I diabetes is associated with enhanced excretion of the endocytic multiligand receptors megalin and cubilin. Diabetes Care; 32: 1266-1268.

Wasan AD, Butler SF, Budman SH, Benoit C, Fernandez K, Jamison RN. 2007. Psychiatric history and psychologic adjustment as risk factors for aberrant drug-related behavior among patients with chronic pain. Clin J Pain; 23(4):307-15.

Wu WN, McKnown LA, Liao S. 2002. Metabolism of the analgesic drug ULTRAM (tramadol hydrochloride) in human: API-MS and MS/ MS characterization of metabolites. Xenobiotica; 32: 411-425.

Zuppi C, Baroni S, Scribano D, DiSalvo S, Musumeci V. 1995. Choice of the time for urine collection for detecting early kidney abnormalities in hypertensives. Annals Chin Biochem; 32: 373-8. 


\section{دراسة أولية عن تأثير إدمان الترامادول علي سلامة وظيفة وتركيب الأنابيب الكلوية \\ بين مدمنين مصريين}

إبراهيم الصفتي1 ، أميمة الجمل2 ، أحمد شومان3 ، إبراهيم السيد محي الدين 4 ، أماني هارون2 ، هشام صادق2،

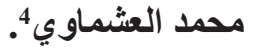

اقسم الكيمياء كلية التربية، مركز الإدمان و الأمر اض النفسية، 3قسم طب المجتمع و البيئة وطب الصناعات كلية الطب جامعة عين شمس، 4قسم الكيمياء كلية العلوم جامعة بورسعيد.

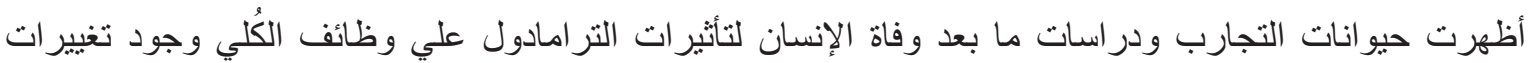

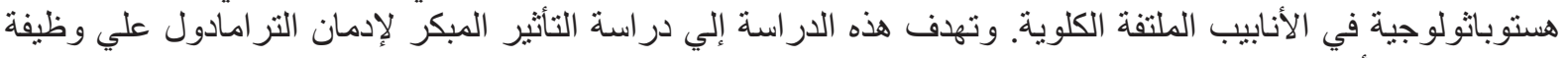
وتركيب هذه الأنابيب الملتفة الكلوية.

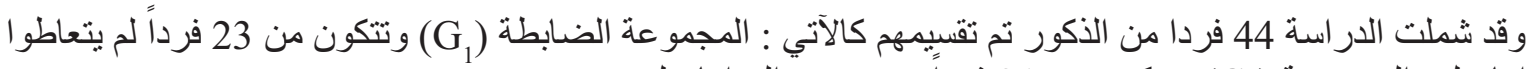

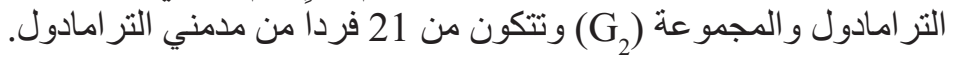

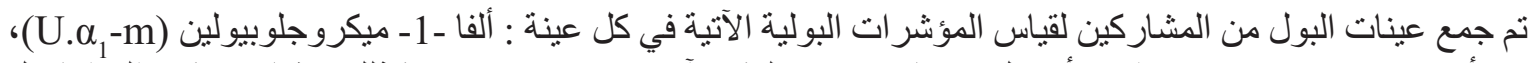
ليوسين أمينو بيتيديز (U.LAP))، إن - أسيتيل - بيتا - دي - جلوكوز آمينيديز (U.NAG). كذلك تم قياس تركيز الترامين امادول بالبول (U.Tr) في عينات (G) (G)

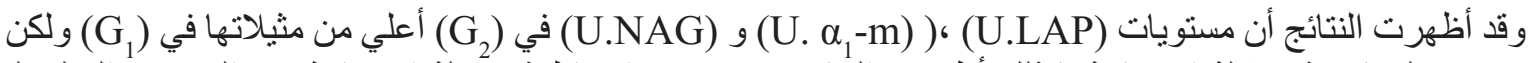

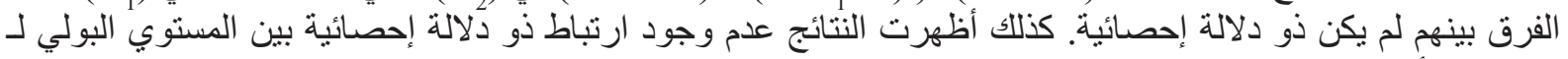
(U.Tr)

ولذلك فإن إدمان الترامادول قد يؤثر علي الأنابيب الملتفة الكلوية. وهذه الدراسة تقيبم أولي للتأثير الكلوي قبل الإكلينيكي 